\title{
Laborer Identification and Monitoring System: Dactyloscopy on the Plantations of East Sumatra, 1926-1980
}

\author{
Erond L. Damanik \\ Department of Anthropology, Faculty of Social Sciences, Medan State University \\ Jl. Willem Iskandar Psr. V, Kenangan Baru, Medan, Sumatera Utara - Indonesia \\ "Corresponding author: eronddamanik@unimed.ac.id \\ DOI: https://doi.org/10.14710/jscl.v6i1.33565
}

Received: 17 October 2020; Revised: 26 October 2021; Accepted: 27 October 2021

\begin{abstract}
This study aims to explore and discuss laborer identification and monitoring systems on East Sumatran plantations during 19261980. It is focused on the implementation of dactyloscopy, archives that have never been researched it all, which had replaced the anthropometric identification system as the reference to determine the criminal justice system. The data used is the dactyloscopy archive in the office of the Sumatra Plantation Company Cooperation Agency and the Indonesian Plantation Museum in Medan City. Data were analyzed using a historiographic approach. The study found that dactyloscopy was part of the modernization of the administrative and bureaucratic systems in plantations. The novelty of the study that the implementation of dactyloscopy in plantation communities is in line with the high crime of labor against employers. Therefore, there is a major distinction in the implementation of dactyloscopy before and after the independence which has been influenced by the logic of colonialism and independence. During the colonialism period, dactyloscopy was used to identify and monitor taming laborersin plantations, while post-independence and nationalization it was used as a modern labor control system.
\end{abstract}

Keywords: Dactyloscopy, Identification; Monitoring, Laborer; Plantation.

\section{Introduction}

None of the plantation references in East Sumatra explored the dactyloscopy archive as a study material. Consequently, the historical experience of dactyloscopy became less known. This study is a preliminary examination of the fingerprint-based recording mechanism on the plantations of East Sumatra. This study was motivated by the findings of dactyloscopy archives at the Sumatra Plantation Companies Cooperation Agency (Badan Kerjasama Perusahaan Perkebunan Sumatra [BKS-PPS]) in Medan. This valuable archive of the colonial period until independence has never been studied before. Information on dactyloscopy was obtained in 2014, during a feasibility study on the establishment of the Indonesian Plantation Museum (Museum Perkebunan Indonesia [Musperin]) at the office of the BKS-PPS. In February 2019, a small portion of dactyloscopy was submitted to Musperin as a collection. In addition to dactyloscopy, BKS-PPS also archived Labor Contract.

Although the archives were known in 2014, the opportunity to review them did not arrive until 2019. Wiratma, the Chairperson of the BKS-PPS did not permit a review at the time because it was considered to have opened up old wounds of the plantations in the past. However, Soedjai Kartasasmita (94 years), the founder of Musperin, is permitted to study it in 2019. The dactyloscopy archives in BKS-PPS are from the independence period. The archives from the colonial period had been burned by the Japanese military.

Dactiloscopy is the contribution of geneticbased science in the late $19^{\text {th }}$ Century. It was initially used for criminology but had a wideranging impact on administration and bureaucracy, identification, and monitoring. The plan to implement dactyloscopy in the Indonesia has sparked debates (Nugteren, 2016:67). Debates and cost considerations, implementation 
mechanisms, employee skills, trials, potential benefits, and nationalism movements in China were delayed until 1926. They feared that the dactyloscopy trials on Chinese migrants would have impacts on bilateral relations, the Dutch and Chinese Governments or employers, and Chinese migrant laborers in the colony (Barret, 2012:49; Claver, 2014:27; Nugteren, 2016:69).

The implementation of dactyloscopy was recorded in the Royal Decree, January 16, 1911 (Department van Justitie, 1911:1; Meijer, 1926: 908). The first implementation was carried out on Chinese migrants and foreign tourists on plantations in East Sumatra in 1926 (Meijer, 1926:908). Dactyloscopy was applied to all migrants and indigenous people regardless of their occupation, except in Europe where dactyloscopy was not implemented (Tracy, 2012:11).

Dactyloscopy, according to the 12,050 volumes of Indonesian archives stored in The Hague (Irwin, 1995:28), is a scientific invention of the late $19^{\text {th }}$ Century used for identifying and classifying humans based on their fingerprint records. In the eugenics and social concepts, dactyloscopy is an understanding of the diverse features of the human body. Dactyloscopy is different from Bertillonage, the anthropometric identification system had been implemented since 1898 (Nugteren, 2016:64). Dactyloscopy is an identification technique that compares fingerprints (Maltoni,2009:98).

Fingerprint formation is genetic, permanent, and different in each human, including in twins (Maltoni, 2009:56). Fingerprints describe individual characteristics (Monson, 2019:111; Maceo, 2009:1322; Pankanti, et.al.,2002:1010). Despite serious injuries, burns, scratches, and cuts on the finger, the ridge structure does not change. New skin will regrow with the same pattern from before the injury. The individuality and characteristics of the fingerprint are based on the structure and quantity of the ridge. Fingerprints have ridge patterns and characteristics that allow individuals to be grouped systematically. Grouping is based on fingerprints mold; arch, loop, whorl, andany combination thereof (Galton, 1892:53). Ridge characteristic consists of ridge ending, bifurcation, and dot or island (Galton, 1892:55).The average fingerprint has 150 ridge characteristics. One group of fingerprints, for example, is based on 10 and 16 specific reference points that correspond to each other. Dactyloscopy serves to track physical genetic potential correlated with talent, intellect, motivation, and character (Misbach, 2010:3; Waits, 2016:32).

Dactyloscopy is related to criminology (Rafael, 1999:11; NIJ, 2016:2; Langenburg, 2009:571; Maceo,2005: 1322; Tortora and Grabowski, 1993:26; Berry, 2001:40; Cole, 2002:24; Lamond, 2011:42). In Babylon and Ancient China, fingerprints were a means of criminal identification. Fingerprints were printed on clay to identify sadistic criminals. Roman lawyers in $1000 \mathrm{AD}$ used palm prints to try murderers (Cole, 1998:42). As an identification technique, dactyloscopy was discovered in Europe but was systematically applied in 1858 in Bengal (Waits, 2016:18). The standard method of fingerprint classification was introduced in 1892 (Galton, 1892; Waits, 2016:18). Dactyloscopy was used as evidence against Thomas Jennings who killed Charles Hiller during a robbery in 1910 (Maltoni, 2009:56). Although the use of dactyloscopy had been largely associated with criminal law since 1911 it also had been used as social implications to control individuals (Cole, 1998:67).

Dactyloscopic trials were conducted in East Sumatra on Chinese, Indian, Javanese, and foreign migrants based on the following considerations: (1) larger number of migrants compared to residents, (2) population heterogeneity, and (3) capital area, economic factors of oil palm plantations and mines. The two factors that contributed to this were (1) tobacco plantations, pioneered by Nienhuijs in 1863 in Deli, and (2) oil mining, discovered by Janszoons in 1883 in Langkat (Nugteren, 2016:34-36).

The plantation sector played an important role for more than a century in the Colonial State (O’Malley, 1988:128; Cooperus, 1924:33; Nas, 1997:154; Blink, 1926:128; Buiskool, 2005:275; Dunn, 2003:47; Middendorp, 1929:47; Passchier, 1995:77; Pelzer, 1978:8; Damanik, 2016a; Damanik, 2016b; Hidayat and Damanik, 2018, Damanik, 2020a). In essence, plantations were determinants of modernization in East Sumatra based on industrial production (Bosma, 2013:41; 
Perret, 2010: 21; Tilley, 2020:19; Damanik, 2017). Initially, Chinese laborers were imported from the Malacca Peninsula and Singapore (Kartodirdjo, 1991:11). The restrictions on Chinese laborers in 1883 and the diversification of plantations had implications for laborer imports from Java and India (Breman, 1992:12; Mondan, 1992:18; Pelzer, 1978:4; Reid, 1979:67; Stoler, 1985:57).

In Deli, 260,591 migrant laborers in 1930; consisting of 26,037 Chinese laborers and 234,554 Javanese laborers registered on plantations. Both populations were not only found on plantations but also outside plantations. Based on the 1930 population census, there were 781,915 migrant populations with the following composition: (1) 192,079 China, consisting of 26,037 registered laborers on plantations and the rest, 166,042 outside plantations, (2) 589,836 Javanese, consisting of 234,554 laborers registered on plantations and the rest, 355,282 outside plantations, (3) 228,805 Europeans. The original inhabitants of Deli consisted of 334,870 Malays, and 145,429 Karonese (Breman, 1992:57; KianWie, 1977:42). Population residing in East Sumatra was based on the following race and origin: (1) 882,189 were local migrants, consisting of Javanese, Toba, Mandailing, Minangkabau, Sunda, Banjar, and Aceh, (2) 580,879 native inhabitants consisting of Malays, Simalungun, and Karo, (3) 228,805 Europe, (4) 260,591 China, and (5) 4,057 India (Reid, 1979:24). The population in 1930, based on the data above, consisted of $1,375,642 \quad(70.31 \%)$ migrant and 580,879 (29.68\%) indigenous.

Plantation laborers in 1928-1938 were classified into three groups; (1) poenalie sanctie laborers, (2) contract laborers, and (3) casual laborers. In 1929, 320,502 laborers on plantations, consisting of 266,234 poenalie sanctie, 35,478 contract laborers and 18,790 casual laborers. The number of laborers in 1938 totaled 208,406, consisting of 4,670 poenalie sanctie laborers, 185,360 contract laborers, and 18,376 casual laborers. Poenalie sanctie is a criminal sanction for breach of the work contract, effective in 1880 and revoked in 1930. Poenalie sanctie is a consequence of the Coolie Ordinance which regulated contractual work relations (Reid, 1970:83; 1979:24).
Reorganization of laborers in the first three decades of the $20^{\text {th }}$ Century was carried out after the publication of van den Brand's Millions of Deli (Brand, 1902; Clemens and Lindbald, 1986:98; Dingemans, 1921:3822-3824, Djawa Tengah, 1929:4; Pewarta Deli, 1931:2). A large number of laborers on plantations required very tight control and supervision. Toean keboen or entrepreneur often employed draconic measures. In addition to riots, the laborers also attacked their toean keboen, supervisors, assistants, and foremen. The most common reason was being scolded for work carried out improperly or wage payment fraud. Many laborers fled because of their suffering. However, due to the difficulties of living in their hometown, laborers generally chose to stay on the plantations. Gambling practices, night markets, traveling cinema, free sex, plantation money, and opium (Damanik, 2018; Damanik, 2020b) were some of the efforts made to impoverish laborers so that they would stay on the plantation.

In line with Bosma's (2020:109), enslavement on plantations happened both through capture or debt traps. Slavery in different parts of the Indonesian archipelago, dealing not only with the existence and patterns of the slave trade itself but also with its social and sociopolitical implications. A large number of the migrant population required a monitoring and controlling mechanism. More specifically, the colonial government had an interest in identifying and controlling Chinese migrants: (1) the relatively large number of Chinese migrants, (2) the rise of Chinese nationalism, and (3) the ties that Chinese migrants had with their country of origin. The peak of the Chinese exodus to East Sumatra occurred in 1890, after natural disasters and war (Setiono, 2002:11), and the surge in tobacco prices. Control of Chinese migrants, since 1885 , had been carried out through the Chinese Council, led by a captain, lieutenant or major, and overseen by the Ministry of Justice. Tjong Yong Hian (1885-1911) and Tjong A Fie (1911-1921) were popular Prominent Hakka in East Sumatra (Damanik, 2019:329-350).

The rise of Chinese nationalism in 1900 had implications for the Chinese Council's political movements in the Colonial State. The colonial government wished to control the Chinese people directly. The Chinese Council was changed to 
Officials for Chinese Affairs and overseen by the Head Advisor of Chinese Affairs. However, the organization remained unsupervised until the riots of February 1912. The Official for Chinese Affairs, since 1913, was overseen by the Minister of Home Affairs, under the Office of Chinese Affairs to remove the role of intelligence in the organization (Anrooij, 2009:137; Bruin, 1918:37). The concentration of intelligence wished for the administrative improvements to recognize and control each individual through registration mechanisms, databases, or isolated individuals who have the potential to threaten state security. Dactyloscopy was believed to enable identification and monitoring of migrants and each population to maintain power in the Colonies.

Dactyloscopy was carried out by the Deli Planters Association (Deli Planters Vereniging [DPV]) and General Association of Rubber Planters on the East Coast of Sumatra (Algemene Vereniging van Rubber plantters ter Ooskust van Sumatra [AVROS]). DPV is the Deli's entrepreneur association, especially in the tobacco, established in 1879. Meanwhile, AVROS was the rubber entrepreneur association which was established in 1916. After the 1962 nationalization, dactyloscopy was carried out by the North Sumatra Plantation Entrepreneurs Association (Gabungan Pengusaha Perkebunan Sumatra [GAPERSU]), and since 1976 it had been continued by the BKSPPS. In 1980, dactyloscopy was ceased entirely. This study contributes to a new knowledge about dactyloscopy in the modernization of administrative and bureaucratic systems. More specifically, the study focusseson laborer identification and monitoring systems on the plantations.

\section{Method}

A systematic and objective historiographic approach (Abdullah, 2016:1) is used to explore and discuss dactyloscopy policies on plantations. The steps taken include heuristics, criticism, and interpretation. Heuristics is a thorough review of the archives; criticism is academic and interpretative considerations, interpretation of archives. These three steps are intended to find significance, substance, urgency, and meaning. The dactyloscopy archive is one of 12,050 types of Indonesian archives stored in The Hague (Irwin, 1995:28).

The main data source is 715,037 pieces of dactyloscopy archives are available at BKS-PPS and Musperin. Secondary data sources are obtained from references; books, journals, and official websites that examined dactyloscopy. Other secondary sources were board minutes (handelingen volksraad), colony records (kolonial verslag), correspondence (mailrapport), state sheets (staadblad), handover (memories van overgave), and newspapers stored in the National Archives of the Republic of Indonesia (Arsip Nasional Republik Indonesia [ANRI]), Jakarta.

Research materials, dactyloscopy, inventoried, sorted, and classified by sex, year of publication, publishing office, and code. Contextual analysis is used to explain the archives to understand the historical event. Contextuality is inseparable from the concepts of time, continuity, and change. Some examples of archives are inserted as evidence of their implementation on plantations. This historical study was conducted for 7 months (February-August) in 2020 in Medan and ANRI, Jakarta.

\section{Major Informations Contain in Dactyloscopy}

The number of dactyloscopy files at BKS-PPS totals 715,037; they consist of 157,053 archives published by DPV and AVROS, 227,953 published by GAPERSU, and 330,031 published by BKSPPS. The entire archive dates from 1948-1980. 481,996 pages thereof contain dactyloscopy of Javanese laborers, while the remaining 233,041 are about local laborers. Javanese laborers, based on archival records, were classified into two types: (1) 153,786 Javanese imported directly from Java after independence, and (2) 328,210 Javanese who had settled in East Sumatra since the period of colonialism. Local laborers, according to the dactyloscopy archives, were indigenous people; Malay, Karonese, Simalungunese, Tobanese, Mandailingneses, and Pakpaknese who worked on post-independence plantations. Pre-independence dactyloscopy archives of Chinese, Javanese, and Indian laborers are not available because they were burned during the Japanese occupation. 
In terms of gender, there were 509,221 female laborers and the remaining 205,816 were male. Laborers were scattered on various plantations and factories in the East Coast of Sumatra. Most of the archives are in good condition, clean, and legible. They are written on both sides, front and back of the paper. On the front side, it is divided into four sections, namely (1) header, (2) middle-top section, (3) middlebottom section, and (4) bottom section. Dactyloscopy was written on white paper. At the very top of the paper, there is a distinctive elongated color of the plantation-green. Fingerprint records were made using black ink. Figure 1 shows a 1949 dactyloscopy sheet.

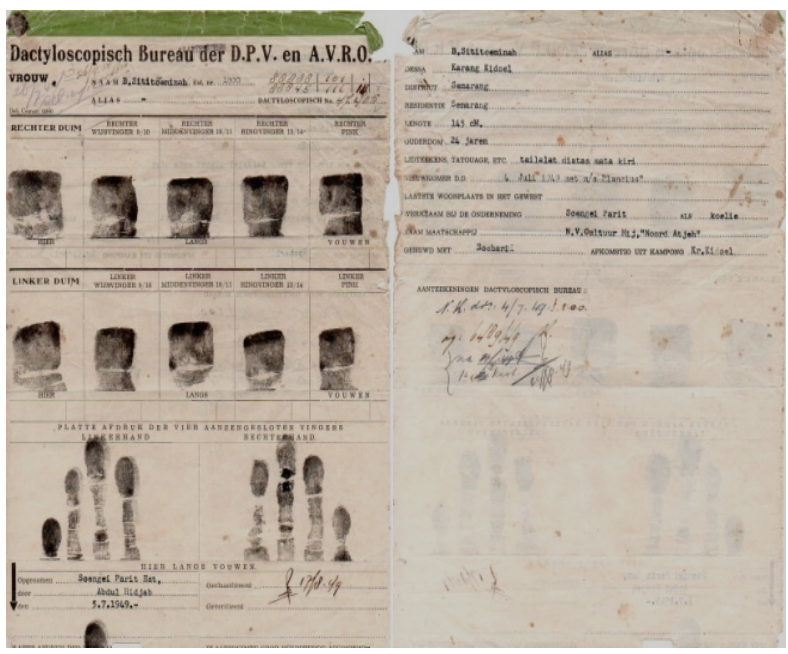

Figure 1. The front and Back Pages of Dactyloscopy Dated 1948.

Source: BKS-PPS Office and Musperin, Medan.

The information in the header contains the name of the company that issued the dactyloscopy, the name of the laborer, alias and gender, company number, number, and fingerprint code. In the middle-top is a recording of 10 right and left fingerprints, made separately in each available box. The middle-bottom sections contain a recording of four right and left fingers without thumbs. At the bottom, it contains information on the location of the issuance, official name, the recording date, counting, and fingerprint investigation. On the lower right side, there are four fingerprint records of the right hand and on the leftside, there is an improved fingerprint recording. The backside of dactyloscopy contains information on the laborer's identity; name, the village of origin, district, regency, height, age, birthmark or tattoo, arrived in Sumatra, place of residence, plantation name, starting work, work position, company name, the origin of the village, and marital status. At the end is a record of the dactyloscopy bureau as well as the filing date.

The laborer in Figure 1 was Siti Toeminah, female, dactyloscopy number 47.405 , working in Sungai Parit under plantation identification number 1000; originating from Karang Kidoel, Semarang, $145 \mathrm{~cm}$-tall, 24 years old, had a birthmark above the left eye, arrived in Sumatra on July 4, 1949, aboard the Plancius, residing in Sungai Parit, working as a laborer at N.V. Cultuur Mij Noord Atjeh, married to Soebari from Karang Kidoel. Fingerprint record dated July 5, 1949, made before Abdul Hidjab and archived on August 6,1949 . The fingerprint code is listed in the upper left corner. Based on archival records, Siti Toeminah was not a problematic laborer. She was never transferred or removed from any plantations. Siti Toeminah was a new laborer imported from Java and worked in Sungai Parit. Meanwhile, Figure 2 is a 1949 dactyloscopy sheet. The information shows a male laborer named Wagiman, aged 20 years, $154 \mathrm{~cm}$-tall, arrived in Sumatra in 1947, lived in Batubara, worked as cranie since January 2, 1949, at the Bilah River estate owned by Holandsch-Amerikaansch Plantage Mij (HAPM). His dactyloscopy number is 228.619. Records show 4 registrations: 17 March 1949, 6 April 1950, 12 September 1956, and 17 October 1956.

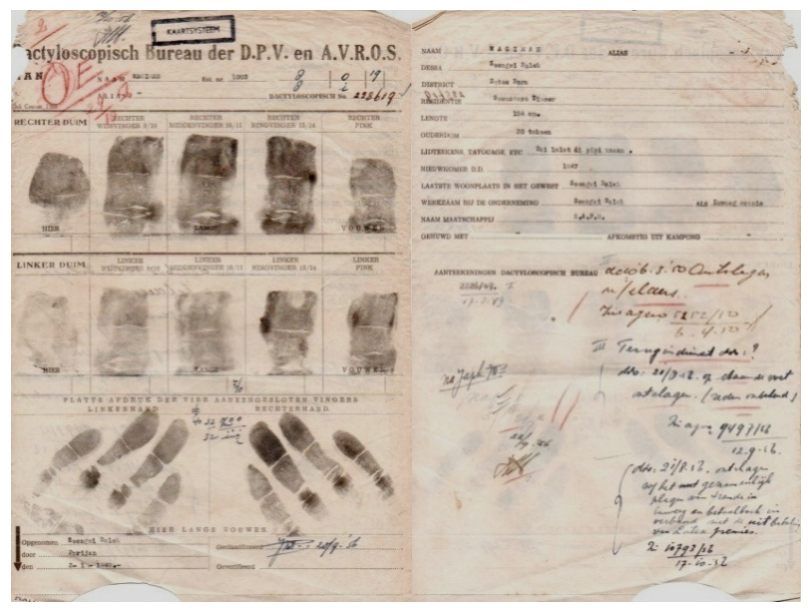

Figure 2 The Front and Back Pages of

Dactyloscopy Dated 1949.

Source: BKS-PPS Office and Musperin, Medan. 
Based on Figures 1 and 2 above, it was found that the dactyloscopy file containing six important information, (a) anthropometric records, (b) fingerprint records, (c) track record, (d) workplace, (e) origin, and (f) marital status. Information, especially the track record, includes a record of employment status (new or moving laborers) and criminals. The six pieces of information are detailed biographical summaries, a kind of actual curriculum vitae but add fingerprint records. More specifically, when a deeper examination is conducted, dactyloscopy stores three main genetic potential informations related to (a) work talent and intelligence of factory or plantation laborer, cranie, foreman, etc., (b) work motivation, and (c) personality,includings attitudes and potentially criminal activities.

Fingerprint recording was useful for refusing, accepting, and even isolating laborers who are considered problematic. In general, the fingerprint code on dactyloscopy at BKS-PPS Medan is: 8888 0-19; 88845-iii-14; 88845-ooi-ii; 88845-0ii-15; 88845-oii-16; 88868-ii0-11-; 8845-i- + 15; 8884500i-21; 88888-ooi-23; 88848-i-15; 88845-0ii-10 and $88845-\mathrm{i}-17$ and many more. Some of the fingerprint recordings on the dactyloscopy file have been damaged by scissors. A friend who worked at BKS-PPS for 25 years could not provide concrete information as to why the fingerprints would be scissored.

In the East Sumatra, fingerprint recording and investigation were carried out by the two largest plantation associations, the DPV and AVROS. In 1911, the DPV formed a labor bureau to recruit laborers for tobacco plantations. DPV established the Deli General Emigration Office (Algemeene Delisch Emigratie Kantoor [ADEK]) in 1919. Both associations, the DPV and AVROS, formed a coalition and renamed ADEK to Vrij Emigratie $D P V$ en $A V R O S$ (VEDA), to organize and supervise a very large number of laborers in East Sumatra (Janssen and Bool, 1939:67). In 1926, when dactyloscopy was first implemented in East Sumatra, VEDA established the DPV and AVROS Dactyloscopy Bureau.

Since 1926, the Bureau had been issuing dactyloscopy for all East Sumatra plantation laborers. Employer and laborer relations became the important focus of the dactyloscopy implementation. For the record, the regulations imposed on employers and laborers early on were the Police Criminal Regulations (Supomo, 1970:52). In 1880, laborers were bound by a contract, Coolie Ordinance which had criminal implications.Both regulations further protected the interests of employers (Soegiri and Cahyono, 2003:4). In 1930, the Coolie Ordinance was gradually abolished and replaced by Free Labor.

Before the implementation of dactyloscopy, the employer-laborer relationship was akin to physical abuse (van den Burg, 1898: 742). Laborers were considered uncivilized (Hannegraff, 1910:17-29; Mulier, 1903:65), the foreman was authorized to torture and confine laborers (Dixon, 2013:49), riots and strikes by laborers were submitted to the police (Kooreman, 1903:54; Brand, 1904:55; Bool, 1904:157),escaped laborers were sentenced to caning and chains (Haarsma, 1889:213), fired laborers could be sold to other companies (Broersma, 1919:239), laborers were punished by being bound, chained, fined or forced to labor (Hoetink, 1903:73; Rookmaker, 1904:810). In essence, the laborers were constantly overshadowed by terror and torture. Their conditions were very dire because of the practice of ordinances (Kooreman, 1904:87).

\section{Sadistic Crimes and Laborer Attacks in the Plantation Company}

Coolie is a typical colonial term, with derogatory meaning and synonymous with oppression (Breman, 1992:24; Houben and Lindblad, 1999:43; Kooreman, 1904:32; Kol, 1903:99; Lubis, 1982:5; Lulofs, 1987:19; Malaka, 2014:57; Sairin, 2014:4; van den Burg, 1898:341).During the years 1885-1930, every month there was a commotion, assault, and murder (Devi, 2004: 47). Laborers were considered rebellious and tortured. In 1913, 42 cases of assaults on Europeans (Devi, 2004:187). 29 cases were by Javanese laborers, 12 cases by Chinese laborers, and 1 case by Banjar laborers. 41 cases were directed at assistants and one case was against a plantation administration (Devi, 2004:189). The Javanese and Chinese laborers had been carried out eight attacks in groups. 
The weapon used in four cases was a hoe, in ten cases it was a machete, in nine cases it was a knife, in seven cases it was a log, in a case used a sickle, it was an ax, in one case it was a gun, while in two cases of beatings and ten other cases of weapons used were not known. The attack resulted in one death, 11 seriously injured, 14 minor injuries, 16 failed cases. There were two cases of attacks occurred in Bandung Estate, two cases in Siharan, two cases in Tanah Raja, while in Mabar and Medan Estate there were three cases each. The sentences varied greatly, ranging from three to six months in prison, fines of 5-100 guilders to one to eight years of forced labor.

In 1924, a newspaper named Andalas, recorded some assaults and murders of plantation assistants from 1912-1923. The assaults were carried out using sharp weapons such as knives, hoes, and sickles. In 1923 for example, 19 individual cases and six collective cases were by Javanese laborers, while five individual cases and one collective were by Chinese laborers. 16 cases occurred in tobacco plantations and the rest in other plantations. 22 cases were directed at Europeans and nine at Indians and Chinese. The history of plantations in East Sumatra, as described by Breman, Said, and van den Brand, was of torture and slavery in the Modern Age. Many laborers were imprisoned, fined, and even sentenced to forced labor. Many laborers suffered, lived a poor life, malnourished, sickened, and died.

Various cases had been submitted to the court. Murder, especially of Europeans as well as propaganda against planters, was considered a sadistic crime. Perpetrators were imprisoned, fined, tortured, or forced to labor. Fingerprint codes, in addition to being useful forisolating troubled laborers, also served to expose criminal acts (Rafael, 1999:57). The Binjai Court of 1930, for example, the fingerprints were used to decide on the Jimat (amulet) case because they were considered to be propaganda against plantations. The court was presided over by J.B. Kan who sentenced each defendant with four years, two years, one and a half years, one year, and seven months in prison (Pewarta Deli, 1930:2). Another case was the attempted assassination of Assistant Muller in Sungai Putih by a Javanese laborer named Doolradjil. The Medan Court sentenced him to chains and four years of forced labor (Djawa Tengah, 1930b:2). Also, the Medan Court sentenced Chinese laborers who attacked Assistant Wegmann at the Rotterdam Plantation to eight years of forced labor and chains (Djawa Tengah, 1930c:3). Another case is a Bumiputra laborer named Kasan in Bandarmaria, who strangled and hit a foreman. He was sentenced to five years of forced labor (Djawa Tengah, 1930d: 2).

Even though dactyloscopy sparked debates, entrepreneurs tried to approach the GovernorGeneral, to implement dactyloscopy. Employers' considerations were; (1) the high number of assaults and killings committed by laborers, (2) violations of work contracts, (3) laborers who fled and changed occupation, and (4) fears of employing problematic laborers. Wettum, the Advisor on Chinese Affairs in Medan, was concerned about the implementation of dactyloscopy among Chinese laborers on plantations. The Chinese had bad experiences with fingerprints, associating it with sadistic criminals. The post-reform Chinese political movement among Chinese Youths was also believed to trigger anti-Western sentiment, and the Chinese in Deli had strong ties with the Chinese dynasty. Another consideration was that the Chinese Consul in Singapore and the Chinese Ambassador in The Hague most likely would refuse dactyloscopy (Wettum, 2010:843).

\section{Implementation of Dactyloscopy for Criminal Justice}

The Resident of East Sumatra and Wettum sent a letter to Idenburg, reporting that Tjong Yong Hian and Tjong A Fie, the Hakka Leaders in Medan, were loyal to their country. Johan, a controleur in Deli, was of different views. Most of the Chinese laborers were poor people in their country, so they could not rebel (Wettum, 2010:841). Wettum and Johan offered a solution; (1) the fingerprint recording was witnessed by the Chinese Council, (2) if dactyloscopy is refused, the Chinese Council is prohibited from trading opium, (3) laborers who refused dactyloscopy were deported to their country at the expense of the Chinese Council, and (4) promise of equal rights such as Britain and China in Singapore (Nugteren, 2016:69). 
In the East Sumatra, dactyloscopy was commonly used to reduce high crime rates. With fingerprint recording, laborers were subject to anxiety and came to fear criminal actions. Chinese laborers had a bad memory on fingerprints in their country, sadistic criminals (Wettum, 2010), and slowly showed a decrease in criminal activities. A similar reality was also found among Javanese laborers. Since the implementation of dactyloscopy, their criminal activities had dropped dramatically. Archival sources in the form of a carefully studied newspaper from 1932-1942, showed low crime rates after the dactyloscopy was implemented.

In the Colonial State, Bertillonage was replaced by dactyloscopy with the three reasons below (Nugteren, 2016:64). The dactyloscopy mechanism was believed to subject individuals to consolidated official identities in databases and identification cards. It was implemented based on the following considerations: (1) the Bertillonage system was considered ineffective because it was prone to errors, (2) difficulty in identifying populations of various races, and (3) identification of population played a role in maintaining the position of the colonial government (Department van Justitie 1910:2). Based on these three considerations, dactyloscopy must be implemented even if it was expensive (Nugteren, 2016:69).

After independence, the implementation of dactyloscopy was made even strict. The situation in East Sumatra after the social revolution of 1946 and the $1^{\text {st }}$ and $2^{\text {nd }}$ Dutch Military Aggression in 1946-1948 was associated with the destruction and looting of plantations. Dactyloscopy was republished in 1948 after the Round Table Conference (Konferensi Meja Bundar [KMB]) in The Hague. The self-governing (swapraja) families who survived the social revolution, Dr. Mansoer, Kaliamsyah Sinaga, and Djomat Purba, the top officials of the United Republic of Indonesia (Republik Indonesia Serikat [RIS]) under Dutch command, wished to take over plantations (Langenberg, 1979:213; Said 1976:413). During the RIS regime in 1948-1950, dactyloscopy was used as a means of identifying and monitoring every laborer working on plantations.
In the era of the Revolutionary Government of the Republic of Indonesia (Pemerintahan Revolusioner Republik Indonesia [PRRI]), 19551957, plantations became a means of smuggling by the North Sumatra Army Territory (Tentara Teritorium Sumatra Utara [TTSU]). The army commander, Maludin Simbolon for example, had smuggled rubber from Nibung Bay. The proceeds were then used to buy weapons and build housing facilities for the army (Bangun, 1996:87). Although dactyloscopy was published, it was inadequate in controlling the looting of plantations which was generally carried out by the army, paramilitary, and the community.

After the nationalization of 1962, dactyloscopy continued to be used for the identification and monitoring of laborers on plantations. However, identification and monitoring were more emphasized in the search for potential laborers for overall improvement in plantations including recovery of plantations destroyed by the war, factory repairs, and the search for capable employees. Dactyloscopy at that particular moment was directed more towards tracking intelligence, motivation, and character. After the nationalization in 1962, dactyloscopy was carried out by the GAPERSU, and since 1976 it had been continued by the BKS-PPS until its cease in 1980. The main reason for the cease of dactyloscopy was associated with plantation reform and the public order bureaucracy.

Since 1980, dactyloscopy has fallen under police jurisdiction, issuing affidavits, criminal records, and statements of good behavior from the police (Surat Keterangan dan Catatan Kriminal $[\mathrm{SKCK}])$. Every job applicant, at any agency, including plantations, is required to attach an SKCK which includes a fingerprint record. SKCK's habit of recording fingerprints is still in effect today, every time it's issued by the police. This indication reinforces the initial assumption that dactyloscopy is closely related to the identification and monitoring of criminal potential. In the end, dactyloscopy, on the one hand, contributes to the improvement of the worker identification and monitoring system, and on the other hand, marks the end of modern forms of slavery.

This study found three important points: (1) the implementation of dactyloscopy during 
1926-1942 had slowly reduced criminal acts on plantations, (2) dactyloscopy in 1948-1962 was more to provide security guarantees for plantations, and (3) the implementation of dactyloscopy in 1962-1980 was more directed at the discovery of genetic potential related to labor talent and intelligence as well as motivation and personality.The strong desire of entrepreneurs in East Sumatra to implement dactyloscopy was driven by the British success in India (Bayly, 1996:4; Bosma, 2013:42). Employers needed detailed information on each laborer to ensure the security and sustainability of plantations.

The implementation of dactyloscopy on plantations reflects the history of international standardized rational administration and bureaucracy. This policy resembles a passport, entry permit, and visa, and residential permit. Every laborer and migrant, foreign tourist, and native inhabitants of East Sumatra are identified in the database. The track record was recorded, checked, and monitored regularly. Recording mobile identities from informal into a more standardized form through recording body features, especially fingerprints. Identity categorization placed isolated individuals in a single and monitored identity. Recording identity encouraged emigration regulations that require permission to enter or leave the area (McKeown, 2008: 31; Torpey, 2000: 52).

The racist plantation ecology often triggered labor uprisings (Tilley, 2020:42). Dactyloscopy strengthened the position of Europeans in the Colonies, while migrant and indigenous populations were heavily monitored and supervised. Dactyloscopy was used for criminal investigations and trials, in cases of (1) criminal investigations, (2) foreign criminals, (3) native criminals, and (4) desertion from Royal Dutch East-Indies Army (Koninklijke NederlandschIndische Leger [KNIL]) (Department van Justitie, 1911:4). In fact, throughout 1930-1942, crime on plantations had declined dramatically.

Post-Indonesian independence, the dactyloscopy still bore a resemblance in orientation to that of the colonial period. Uncertain domestic situations, social revolution (1946), the $1^{\text {st }}$ and $2^{\text {nd }}$ Dutch Aggression (19461948), the RIS regime in 1948-1950, until the establishment of the PRRI in 1955-1958 hurt the plantation climate. Plantations became disputed lands between the community, paramilitary forces, aristocrats, and military units. They were looted, annexed, and burned or destroyed and saw cases of smuggling. The use of dactyloscopy in this period, although far from optimal to reduce crime in plantations, had kept the condition of the plantations under strict monitoring. After nationalization (1962-1980), dactyloscopy was focused on capturing potential talents, motivations, and character of laborers to improve post-war plantations. During this period, dactyloscopy became a psychological tool to capture the potential of laborers for the advancement of plantations.

Based on the description above, the implementation of dactyloscopy in plantations is in line with historical logic. The logic during colonialism was that migrants and indigenous people were criminals or rebels who must be identified and monitored. Dactyloscopy according to the logic of colonialism was oriented to the recording of identity in an organized database to facilitate monitoring. The logic during independence was that plantations were the property of the State which must be maintained and developed as one of the country's economic resources. Dactyloscopy, according to the logic of independence was oriented towards identifying and monitoring genetic potential that contributes to the growth of post-colonialism plantations.

\section{Conclusions}

The findings of the study are that dactyloscopy served to standardize identities to obtain information and potential crimes that might threaten plantations. Dactyloscopy helped plantation owners identify and monitor each laborer's movement. This study concludes that the implementation of dactyloscopy on plantations served to identify and monitor laborers. Its implementation was influenced by the logic of colonialism and independence. The logic of colonialism viewed the natives and migrants in the Colonial State as criminals or rebels who must be monitored. Dactyloscopy encouraged the recording of physical features identity in an 
information system to identify and monitor laborers' crimes and actions. The logic of independence encourages the use of dactyloscopy in the screening of genetic potential that correlates with talent, motivation, and personality that contribute to the development of plantations. Dactyloscopy is an identification and monitoring tool whose role is to create a database containing detailed information about laborers regularly. The study recommends the importance of research on aspects not yet covered, economic contributions or benefits obtained as well as changes achieved before and after the application of dactyloscopy on plantations.

\section{References}

Abdullah, T. (2016). Historiografi dalam denyut sejarah bangsa. Kalam: Jurnal Kebudayaan, $28(1), 1-26$.

Andalas, January 19, 1924. Penyerangan pada Asisten Kebon.

Anderson, J. (1971). Mission to the East Coast of Sumatra in 1823. Kuala Lumpur: Oxford in Asia Historical Reprints.

Anrooij, F. (2009).De Koloniale Staat, 18541942: gids voor het archief van het ministerie van Koloniën: de Indonesische archipel. Den Haag: National Archief.

Bangun, P. (1996).Kolonel Maludin Simbolon: Lika liku perjuangannya dalam pembangunan bangsa. Jakarta: Sinar Harapan.

Barret, T. (2012). The Chinese diaspora in SouthEast Asia: The Overseas Chinese in IndoChina. London: I.B. Tauris.

Bayly, C. (1996). Empire and information: Intelligence gathering and social communication in India, 1780-1870. Cambridge: Cambridge University Press.

Berry, J., and Stoney, D. (2001). History and development of fingerprinting. In H.C. Lee and R.E. Gaensslen(eds). Advances in Fingerprint Technology. (1-40). Florida: CRC Press.

Blink, H. (1926). Opkomst en ontwikkeling van Sumatra als economisch-geografphisch gebied. S-Gravenhage: Mouton.
Bool, J. H. (1904). De practijk der KoelieOrdonannantie. Amsterdam: Hoverer \& Wormser.

Bosma, Ulbe (2020). Commodification and slavery in the Nineteenth-Century Indonesia Archipelago. Journal of Social History, 54 (2), 109-124. doi.org/10.1093/jsh/shaa009.

Bosma, U. (2013). The sugar plantation in India and Indonesia: Industrial production, 17702010. Cambridge: Cambridge University Press.

Breman, J. (1992). Koelies, Planters en Koloniale Politiek. Leiden: KITLV Uitgeverig.

Breman, J. (1998). Penguasaan tanah dan tenaga kerja Jawa di masa kolonial. Jakarta: LP3ES.

Broersma, R. (1919). Ooskust van Sumatra: De ontluiking van Deli. Batavia: Javasche Boekhandel de Drukkerij.

Bruin, A. G. de. (1918). De Chineezen ter Ooskust van Sumatra. Leiden: Ooskust van Sumatra Instituut.

Buiskool, D. (2005). Medan: A Plantation City on the East Coast of Sumatra 1870-1942. In Freek Colombijn (ed.). Kota lama kota baru: Sejarah kota-kota di Indonesia sebelum dan setelah kemerdekaan. (275-300). Yogyakarta: Ombak.

Claver, A. (2014). Dutch commerce and chinese merchants in Java: Colonial relationships in trade and finance, 1800-1942. Leiden \& Boston: Brill.

Clemens, A.H.P and Lindbald, J. (1986). Het belang van de buitengewesten: Economische expansie en koloniale staatsvorming in de Buitengewesten van Nederlands Indie 18701942. Amsterdam: NEHA.

Cole, S. (1998). Manufacturing identity: A history of criminal identification techniques from photography through fingerprinting. Ann Arbor: Indiana University Press.

Cole, S. (2002) Suspect identities: A history of fingerprinting and criminal identification. Journal of the History of Biology, 35 (1), 204206.

Couperus, L. (1924). Oostwaarts. Gravenhage: Leopold.

Damanik, E. L. (2020a). Nurturing the collective memory of plantation traces. Paramita: Historical Studies Journal, 30(2), 121-134. 
doi.org/10.15294/paramita.v30i2.18509

Damanik, E. L. (2020b). Perdagangan dan pemertahanan kuli di perkebunan: Opium di Deli, 1870-1942. Jasmerah, 2(1), 1-19, doi.org/10.24114/jasmerah\%20journal.v2i1. 17990

Damanik, E. L. (2016a). Danau Toba: Permata mahkota Pulau Sumatra. Medan: Simetri Institute.

Damanik, E. L. (2016b). Kisah dari Deli: Historisitas, pluralitas dan modernitas Kota Medan tahun 1870-1942. Medan: Simetri Institute.

Damanik, E. L. (2017). Kisah dari Deli: Masalah sosial dan pembangunan di Kota Medan. Medan: Simetri Institute.

Damanik, E. L. (2018). Opium di Deli: Perdagangan, konsumsi dan pelarangan, 1774-1956. Medan: Simetri Institute.

Damanik, E. L. (2019). Inter-race, religion, and cultural tolerance: the spread of Buddhism by Tjong Family's in Medan, North Sumatra, Indonesia. In Thich $\mathrm{Na}$ Thu (ed.). Buddhism around the world. (329-350). Vietnam:

Religion Publisher.

Departement van Justitie (1911). Daktyloscopie. Jakarta: ANRI.

Devi, T. K. (2004). Poenale sanctie: Studi tentang globalisasi ekonomi dan perubahan hukum di Sumatera Timur, 1870-1950. Medan: USU Press.

Dingemans, A. J. E. (1921). In memoriam Mr.J. Van den Brand. De Planters, 12:3822-3824.

Dixon, C. J. (1913). De assistent in Deli: Practische opmerkingen met betrekking tot den omgang met koelies. Amsterdam: De Bussy.

Djawa Tengah. February 20, 1929. Amerika Serikat dan poenale sanctie.

Djawa Tengah. April 1, 1930a. Dihoekoem.

Djawa Tengah. April 23, 1930b. Dihoekoem kemaren doeloe.

Djawa Tengah. June 21, 1930c. Diberi hoekoeman.

Dunn, P. (2003). The City of Medan: the continuation of history. Report of a Mission on Integrated Conservation of Medan's City Center, No. 20587 MIC.

Galton, F. (1892). Fingerprints. London:
MacMillan.

Haarsma, G. (1889). De Tabakscultuur in Deli. Amsterdam: De Bussy.

Hannegraaff, A. (1910). Hoe het thans staat met den assistent en de veiligheid aan de Oostkust van Sumatras. Gravenhage: van der Beek.

Hidayat and Damanik. E. L. (2018). Batak dan bukan Batak: Paradigma sosiohistoris tentang konstruksi identitas etnik di Kota Medan, 1906-1939. Jurnal Sejarah Citra Lekha, 3(2), 71-87

Hoetink, H. R. (1903). De brochure van Mr. Van den Brand over Deli. De Indische Gids, 45, 46-17.

Houben, V. J. (1999). Coolie labour in colonial Indonesia: A study of labour relations in the Outer Island, c. 1900-1940. Wiesbaden: Harrassowitz.

Irwin, G. (1995). Sumber-sumber sejarah Belanda. In Soedjatmoko (ed.). Historiografi Indonesia: Sebuah pengantar. (208-227). Jakarta: Gramedia.

Janssen, C.W and Bool, H.J. (1939). Senembah Maatschappij 1889-1939. Amsterdam: Boeken kunstdrukkerij.

Kartodirdjo, S. (1991). Sejarah perkebunan di Indonesia: Kajian sosial ekonomi. Yogyakarta: Aditya Media Publishing.

Kian-Wie, T. (1977). Plantation agriculture and export growth: An economic history of East Sumatera, 1863-1942. Jakarta: LIPI.

Kooreman, P. J. (1903). De koelie-ordonanntie tot regeling van de rechtsverbouding tusschen werkgevers en werklieden in de residentie Ooskust van Sumatra toegelicht: Lezing. Amsterdam: De Bussy.

Kooremann, P. J. (1904). Get debat in de Tweede Kamer der Staten-Generaal over het rapportRhemrev. Organ der Vereeniging Moederland en Kolonien, 5(1),1-80

Lamond, G. (2011). An introduction to dactyloscopy. Retrieved from URLOctober 10, 2019, from

http://www.crimtrac.gov.au/systems_projec ts/Fingerprints.html

Langenberg, M. (1976). National revolution in North Sumatra: Sumatera Timur and Tapanuli 1942-1950. Sydney: Sydney University Press. 
Lubis, M. (1982). Kuli kontrak. Jakarta: Sinar Harapan.

Lulofs, M. S. (1987). Koelie. Oxford: Oxford University Press.

Maceo, A. (2005). The basis for the uniqueness and persistence of scars in the friction ridge skin. Fingerprint Whorld, 121(31),147-161.

Maceo, A. (2009). Friction ridge skin: Morphogenesis and overview. In A. Jamieson A (Ed.). Wiley Encyclopedia of Forensic Science (1322-1331). Chichester, UK: Wiley.

Malaka, T. (2014). Dari penjara ke penjara. Jakarta: Narasi.

Maltoni, D. (2009). Handbook of Fingerprint Recognition (2nd ed.). London: Springer.

McKeown, A. (2008). Melancholy order: Asian migration and the globalization of borders. New York: Columbia University Press.

Meijer, D. H. (1926). Dactyloscopie voor Nederlandsch-Indie. Koloniale Studien, 9, 908-947.

Middendorf, W. (1929). The administration of the outer provinces of the Netherlands Indie. In B. Schrieke (Ed.). The Effect of Western Influence on Native Civilisations in the Malay Archipelago. (34-70). Batavia: Royal Batavia Society of Arts and Sciences.

Misbach, I. (2010).Dahsyatnya sidik jari: Menguak bakat dan potensi untuk merancang masa depan melalui fingerprint analysis. Jakarta: Visi Media.

Mondan, A. and Suryo, D. (1992). Bayang-bayang harapan di Tanah Dollar: Penderitaan kuli kontrak perkebunan di Sumatera Timur.Yogyakarta: UGM Press.

Monson, K. L. (2019). The permanence of friction ridge skin and persistence of friction ridge skin and impressions: A comprehensive review and new results. Forensic Science International, 297: 111-131. doi.org/doi.org/10.1016/j.forsciint.2019.01. 046.

Mulier, W. J. H. (1903). Arbeidstoestanden op de Ooskust van Sumatra. Medan: Deli Courant.

Nas, P. J. M. (1997). Colonial City. Leiden: University of Leiden.

National Institute of Justice (2016). The Fingerprints: Sourcebook. Washington, D.C.:
Department of Justice Office of Justice Programs.

Nugteren, B. (2016). The impossible colonial border: Chinese migration and immigration policies in the Netherlands East Indies, 18801912. Leiden: Leiden University.

O'Malley, W. (1977). Indonesia in the Great Depression: A study of East Sumatera and Jogjakarta in the 1930s. Ithaca, NY: Cornell University.

Pankanti, S., Prabhakar, S., and Jain, A. (2002). On the individuality of fingerprints. IEEE Transactions on Pattern Analysis and Machine Intelligence, 24(8),1010-1025

Passchier, C. (1995). Medan, urban development by Planters and Entrepreneurs, 1870-1940. In P.J.M. Nas (Ed.). Issues in Urban Development: Case studies from Indonesia. (47-64). Leiden: CNWS Publication.

Pelzer, K. J. (1978). Planter and peasant: Colonial policy and the agrarian struggle in East Sumatra 1863-1947. Leiden: Brill.

Perret, D. (2010). Kolonialisme dan etnisitas: Batak dan Melayu di Sumatera Timur Laut. Jakarta: KPG dan EFEO-Jakarta

Pewarta Deli. February 25, 1930. Perkara djimat dalam keboen. Toedjoeh orang mandoer dan koeli dimoeka pengadilan.

Pewarta Deli. October 1, 1931.Poenale sanctie dihapuskan.

Rafael, V. (1999). Figures of criminality in Indonesia, the Philippines, and Colonial Vietnam. Ithaca: Cornell University Southeast Asia Program.

Reid, A.(1970). Early Chinese migration into North Sumatera. In J. Chen and N. Tarling (Eds). Studies in the social history of China and Southeast Asia. (293-317). London: Cambridge University Press.

Reid, A. (1979). The blood of the people: Revolution and the end of traditional rule in Northern Sumatra. Kuala Lumpur: Oxford University Press.

Rookmaker, H.(1904). Voordracht gehouden op 18 november voor de Nederlansche afdeeling van de Nederlansch-Indische Maatschappij van Nijverheied en Landbouw. De Indische Mercuur, 27: 808-816.

Said, M. (1976). Medan area merebut 
kemerdekaan. Medan: Biro Sejarah Prima.

Said, M. (1977). Koelie kontrak tempo doeloe dengan derita dan kemarahannya: Suatu zaman gelap di Deli. Medan: Waspada.

Sairin, S. (2014). Dari ancak ke ancak: Buruh Jawa di perkebunan Sumatera Utara pada masa Orde Baru. Yogyakarta: UGM Press.

Setiono, B. (2002). Tionghoa dalam pusaran politik. Jakarta: Elkasa.

Soegiri and Cahyono, E. (2003). Gerakan serikat buruh jaman Kolonial Belanda hingga Orde Baru. Jakarta: Hasta Mitra.

Stoler, A. L. (1985). Capitalism and confrontation in Sumatra's plantation belt, 1870-1979. New Haven: Yale University Press.

Supomo, I. (1970). Pengantar Hukum Perburuhan. Jakarta: Djambatan.

Tilley, L. (2020). A strange industrial order: Indonesia's racialized plantation ecologies and anticolonial estate worker rebellions. History of the Present, 10(1), 1-25.

Torpey, J. (2000). The invention of the passport: Surveillance, citizenship, and the state. Cambridge: Cambridge University Press.

Tortora, G. J. and Grabowski, S. R. (1993). Principles of anatomy and physiology. New York: Harper Collins.

van den Brand, J. (1902). De Millioenen uit Deli. Amsterdam: Hoveker \& Wormser.

van den Burg, C. L. (1898). Bespreking van Dr. P. Adriani, Medische herinneringen aan Deli en Langkat (oost-Sumatra). Tijdschrift van Het Koninklijk Nederlansch Aardrijkskunding Genootschap, 15, 740-743.

Waits, M. R. (2016). The indexical trace: A visual interpretation of the history of fingerprinting in Colonial India. Visual Culture in Britain, $17(1), 18-32$.

Wettum, M. (2010). Chineesche toestanden in Deli: Daktyloscopie. Chineesche toestanden in Deli: Daktyloscopie in: 'Missive van Directeur Justitie Nederburgh, 22 Juli No 843 aan de Raad van Nederlands-Indië en de GouverneurGeneraal.Jakarta: ANRI. 